\title{
GERMINATION OF STORED SEEDS OF FOUR TREE SPECIES FROM THE TROPICAL DRY FOREST OF MORELOS, MEXICO
}

\author{
Martha Cervantes ${ }^{1}$, Eliane Ceccon ${ }^{2}$ and Consuelo Bonfil ${ }^{3,4}$ \\ ${ }^{1}$ Consultora Independiente. Investigadora jubilada del Instituto Nacional de Investigaciones Forestales, \\ Agrícolas y Pecuarias. Campo Experimental Zacatepec, Zacatepec, Morelos, Mexico \\ ${ }^{2}$ Centro Regional de Investigaciones Multidisciplinarias, Universidad Nacional Autónoma de México. \\ Cuernavaca, Morelos, Mexico \\ ${ }^{3}$ Departamento de Ecología y Recursos Naturales. Facultad de Ciencias, Universidad Nacional Autónoma de México. \\ México, D. F., Mexico \\ ${ }^{4}$ Corresponding author: cbonfil@ciencias.unam.mx
}

\begin{abstract}
Studies on propagation of trees of Tropical Dry Forests are scarce in Mexico; besides, the provenance of seeds used in reforestation programs is generally unknown or poorly addressed. Knowledge on seed germination patterns of different provenances, and how they change through time, is useful to identify adequate sources of seeds and to develop seed collection and storage programs under low-tech conditions prevailing in most rural nurseries. We evaluated seed size variation and germination of stored seeds from three different provenances per species in Acacia bilimekii, Haematoxylum brasiletto, Lysiloma acapulcense, and L. divaricatum. Seeds were collected in four sites in the Tropical Dry Forest of Morelos, Mexico, and were stored at room temperature; seed size was estimated through the volume of 75 seeds per provenance/species. Seed germination tests were made periodically from six to 24 months after storage and the effects of provenance and storage time on germination were analyzed using analysis of variance. There were significant differences in seed size among provenances in all species, while the effect of provenance on germination was significant in three of them. Germination changed with storage time among species and provenances. After 24 months, germination capacity was still $\geq 50 \%$ in all provenances of the two Lysiloma species, but in A. bilimekii there were large differences among provenances. Mean germination capacity was low in $H$. brasiletto after six months. More research on seed germination and storage of a larger set of species and provenances is needed to restore Mexican tropical dry forests.
\end{abstract}

Keywords: Acacia bilimekii, Haematoxylum brasiletto, Lysiloma, propagation, provenance, rural nurseries.

Resumen: Los estudios sobre la propagación de árboles de los bosques tropicales secos son escasos en México; además, la procedencia de las semillas usadas en los programas de reforestación generalmente no se conoce o recibe poca atención. El conocimiento de los patrones de germinación de semillas de distintas procedencias, y cómo cambian a través del tiempo, es útil para identificar fuentes de semillas adecuadas para los programas de reforestación y para desarrollar programas de recolecta y almacenamiento en las condiciones de baja tecnología que prevalecen en los viveros rurales. Se evaluó la variación en el tamaño y la germinación de semillas almacenadas de tres diferentes procedencias por especie en Acacia bilimekii, Haematoxylum brasiletto, Lysiloma acapulcense y L. divaricatum. Las semillas se recolectaron en cuatro sitios del Bosque Tropical Seco de Morelos, México, y se almacenaron a temperatura ambiente. El tamaño de las semillas se estimó mediante el volumen de 75 semillas por procedencia/especie. Se realizaron periódicamente pruebas de germinación entre los seis y 24 meses; el efecto de la procedencia y el tiempo de almacenamiento se analizaron mediante análisis de varianza. Se presentaron diferencias significativas en el tamaño de las semillas entre procedencias en todas las especies, mientras que el efecto de la procedencia en la tasa de germinación fue significativo en tres de ellas. La capacidad de germinación cambió con el tiempo de almacenamiento entre especies y procedencias; después de 24 meses, era aún $\geq 50 \%$ en todas las procedencias de las dos especies de Lysiloma, pero en A. bilimekii hubo grandes diferencias entre procedencias. La capacidad germinativa promedio fue baja en $H$. brasiletto después de seis meses. Es necesario realizar más investigaciones sobre germinación y almacenamiento de semillas de un grupo más amplio de especies y sus procedencias para poder restaurar los bosques tropicales secos de México.

Keywords: Acacia bilimekii, Haematoxylum brasiletto, Lysiloma, procedencia, propagación, viveros rurales.

$\mathbf{H}$ uman activities, such as agriculture and cattle ranching, have exerted a considerable pressure on the tropical dry forests (TDF) of America, and Mexico is no exception (Sánchez-Azofeifa and Portillo-Quintero, 2011). As a result, large vegetated areas have disappeared; in addition, a high proportion of the remaining forests have been 
disturbed (Trejo and Dirzo, 2000). At present many forest patches are in a degraded state as a result of frequent forest fires, grazing, and selective species extraction. Therefore, the rehabilitation or ecological restoration of these sites is becoming an increasingly urgent task.

Studies on propagation of Mexican plant species of TDF are scarce, although there is a handful published studies addressing seed viability and germination (CervantesGutiérrez et al., 1996; Cervantes et al., 2001; Cervantes and Sotelo, 2002; Bonfil-Sanders et al., 2008). Seeds of tree species from TDF usually mature during the warm-dry season and are dispersed before the beginning of subsequent wet season (Bullock and Solís-Magallanes, 1990; Singh and Singh, 1992; Ray and Brown, 1994). Many species form a short-lived seed bank lasting a few months, and most seeds germinate at the beginning of the rainy season or lose viability if buried for longer periods (Ray and Brown 1994; Miller, 1999). However, changes in seed viability through time in different species and provenances have seldom been addressed.

Some leguminous TDF trees have been over-harvested in large areas of Mexico, as they are valuable multipurpose species, used either as firewood, building material, or as a source of food or fodder (Cervantes et al., 1998). This over harvesting has resulted in the decline of many populations in the state of Morelos, in central Mexico (Boyás et al., 1993). Most of the remaining populations currently occur only in fragments within protected areas or in inaccessible areas. Small populations are vulnerable to extinction; furthermore, climate and resource fluctuations, demographic variations, reduced genetic diversity and reproductive success are all factors that operate against their long term survival (Rosenzweig, 1995; Brook et al., 2008; Primack, 2010). Therefore, it is becoming increasingly important to develop practical and low-cost methods to collect and store seeds of these hardwoods, in order to increase their propagation in rural nurseries and the establishment of plantations to assist the recovery of small populations, develop agroforestry programs or restore disturbed areas.

The provenance of seeds used in reforestation programs in many areas of Mexico is generally unknown or poorly addressed. Knowledge of variation among provenances in seed size, viability and germination patterns are useful to identify adequate local sources of seeds and increase the success of reforestation and land rehabilitation programs (Thompson, 1997).

Seed size varies along environmental gradients, particularly those related to latitude, altitude and climate, and this variation may affect germination and seedling performance (Dorne, 1981; Lopez-Mata, 1987; Baskin and Baskin, 2001; van Molkën et al., 2005). Seedlings from large seeds have shown higher survival or growth than those from small seeds in experimental and natural conditions (Wulff, 1995; Bonfil, 1998; Khurana and Singh, 2000; Paz and Martínez-
Ramos, 2003; Metz et al., 2010). Therefore, it is important to document variations in seed size among provenances and to find out whether they are related to differences in seed germination patterns. It is also necessary to gather information on seed storability and the potential variation among provenances for storage, as this information will allow the design of adequate collection and storage plans in rural nurseries, most of which lack facilities and store seeds in cans or glass flasks at room temperature.

In this study we evaluated variation in seed size and germination of stored seeds of four over-logged leguminous tree species from the TDF of Morelos, Mexico, in three different provenances per species: Acacia bilimekii J.F.Macbr., Haematoxylum brasiletto H.Karst, Lysiloma acapulcense (Kunth) Benth., and L. divaricatum (Jacq.) J.F.Macb. We described variations in seed size among provenances and compare changes in germination patterns among them over a two year storage period.

\section{Materials and methods}

Study Area. Seeds were collected during the 1996-97 dry season, in four TDF sites of Morelos: (1) Barranca Honda (Tlaltizapán county), (2) Cañón de Lobos (Yautepec), (3) El Tepehuaje (Tepalcingo), and (4) Quilamula (Tlaquiltenango county; Figure 1). The climate in the four sites is hotsubhumid; mean annual temperature is $22-26^{\circ} \mathrm{C}$ and annual precipitation 800-1,000 mm, most of which falls from June to October (García, 2004). Soils are derived either from volcanic rocks (at El Tepehuaje and Quilamula), or limestone (Barranca Honda and Cañón de Lobos; Boyás, 1991). The main environmental characteristics of the four study sites are shown in Table 1.

Seed collection and storage. The amount of seeds collected on each location varied depending on availability, but they

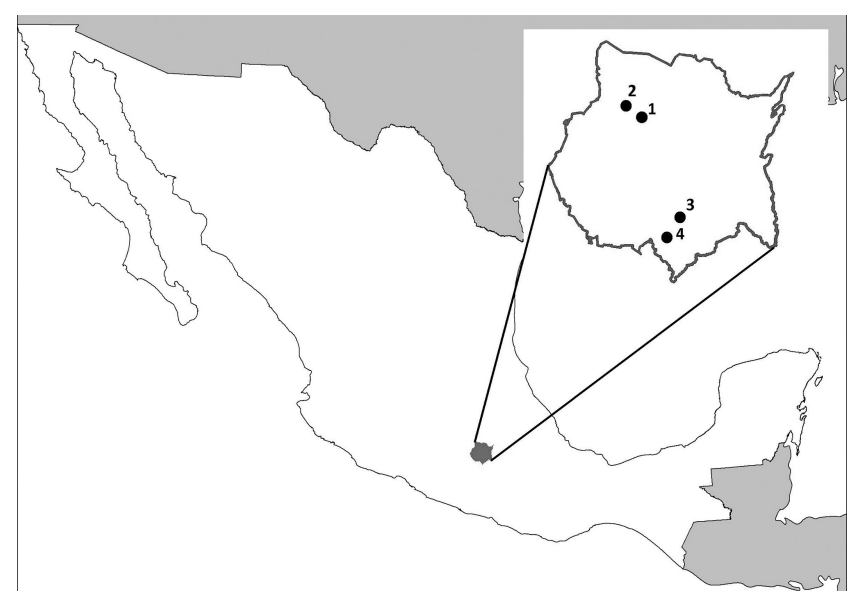

Figure 1. Location of seed provenances in Morelos state, Mexico. 1- Barranca Honda, 2- Cañón de Lobos, 3 - El Tepehuaje, 4- Quilamula. 
Table 1. Coordinates and values of the main climatic variables at the four seed collection sites. BH = Barranca Honda; $\mathrm{CL}=\mathrm{Cañón}$ de Lobos, Tep = El Tepehuaje, Qui = Quilamula. AR = annual rainfall, RDM = rainfall during dry months, MAT = mean annual temperature. Unpublished climatic data from Programa de Agroclimatología, Instituto Nacional de Investigaciones Forestales, Agrícolas y Pecuarias de Morelos (average values 1960-1990).

\begin{tabular}{|c|c|c|c|c|c|c|}
\hline Loc & Latitude N & Longitude W & Altitude (m) & $\mathrm{AR}(\mathrm{mm})$ & $\mathrm{RDM}(\mathrm{mm})$ & MT $\left({ }^{\circ} \mathrm{C}\right)$ \\
\hline $\mathrm{BH}$ & $18^{\circ} 49^{\prime} 46^{\prime \prime}$ & $99^{\circ} 07^{\prime} 05^{\prime \prime}$ & $1,100-1,345$ & 843.3 & 51.3 & 23.1 \\
\hline $\mathrm{CL}$ & $18^{\circ} 51^{\prime} 21^{\prime \prime}$ & $99^{\circ} 07^{\prime} 06^{\prime \prime}$ & 1,190 -1,350 & 880.4 & 39.1 & 20.9 \\
\hline TEP & $18^{\circ} 35^{\prime} 02^{\prime \prime}$ & $98^{\circ} 59^{\prime} 09^{\prime \prime}$ & $1,100-1,435$ & 776.8 & 38.8 & 22.2 \\
\hline QUI & $18^{\circ} 30^{\prime} 46^{\prime \prime}$ & $99^{\circ} 01^{\prime} 52^{\prime \prime}$ & $1,125-1,200$ & 849.5 & 30.8 & 24.7 \\
\hline
\end{tabular}

were obtained from 5-10 trees per site and species. After harvest, fruits were placed in a closed room and fumigated with Aluminum phosphide ${ }^{\circledR}$ to avoid insect attack. Seed extraction and cleaning were made manually and insecticide (commercial brand Decis ${ }^{\circledR}$, active ingredient deltametrin) was applied before seeds were stored in closed glass flasks at room temperature.

Seed size (wide, length, and thickness) of 75 seeds by provenance was measured using calipers. With the measures obtained the volume of each seed was calculated as the volume of an ellipsoid:

$$
\text { Volume }=4 / 3 * \pi * r_{1} * r_{2} * r_{3}
$$

Where: $\mathrm{r}_{1}=$ seed width $(\mathrm{cm}), \mathrm{r}_{2}=$ seed length $(\mathrm{cm}), \mathrm{r}_{3}=$ seed thickness $(\mathrm{cm})$

Seed germination. Three provenances per species were tested, but they varied among species, as not all species were found in the four sites. To evaluate changes in germination through time for each species/provenance, seed germination tests were performed every six months up to 24 months after storage. The seeds were soaked in water for $24 \mathrm{~h}$, after which four replicates of 100 seeds for each species/provenance were placed in plastic trays using sterile sand as substrate. Uncovered trays were randomly placed in wire-mesh tables in a nursery covered with shade plastic mesh $(60 \%$ shade), and were watered daily to keep the substrate moist. Germination was recorded as radicle emergence $(0.5 \mathrm{~cm})$ every other day during five weeks. Final cumulative germination was calculated for each tray and species.

Statistical analysis. The effect of provenance on seed size for each species was analyzed by one way ANOVA; means were compared with post-hoc Tukey tests. Seed size distributions among provenances were compared using chisquare tests. The effect of provenance and time of storage on seed germination was analyzed using a factorial ANOVA with a complete randomized factorial design, in which the factors were storage time and provenance. Germination data were previously arcsine transformed. All statistical analyses were performed using STATISTICA software package v 7.0 (StatSoft Inc., Tulsa, OK, USA).

\section{Results}

Effect of provenance on seed size. We found a considerable variability in seed size among species and provenances. Haematoxylum brasiletto had the smallest $\left(0.18 \mathrm{~cm}^{3} \pm\right.$ 0.004 , mean \pm s.e.) and Lysiloma acapulcense the largest seeds $\left(0.56 \mathrm{~cm}^{3} \pm 0.012\right)$. Differences in seed size among provenances were significant for all species: Acacia bilimekii $\left(F_{(2,72)}=50.1, P<0.01\right)$, L. acapulcense $\left(F_{(2,72)}=37.9\right.$, $P<0.01)$, L. divaricatum $\left(F_{(2,72)}=4.4, P<0.05\right)$, and $H$. brasiletto $\left(F_{(2,72)}=4.2, P<0.05\right)$, but in the latter species they were rather low (Figure 2). In the two Lysiloma species large seeds were found in Quilamula and small seeds in El Tepehuaje.

Differences in seed size distribution among provenances were also significant for all species: Lysiloma acapulcense $\left(\chi^{2}=109.24\right.$, df $\left.8, P \leq 0.001\right)$, L. divaricatum $\left(\chi^{2}=33.52\right.$, df $12, P \leq 0.001)$, Acacia bilimekii $\left(\chi^{2}=67.97\right.$, df $12, P$ $\leq 0.001)$, and Haematoxylum brasiletto $\left(\chi^{2}=377.97\right.$, df 6 , $P \leq 0.0001$; Figure 3). Seed size variation was larger in $L$.



Figure 2. Mean seed size ( \pm s.e.) of three provenances of four species from the tropical dry forest of Morelos (Barranca Honda /////, Cañón de Lobos $\square$, El Tepehuaje $\square$, Quilamula $\equiv)$. Means among provenances are significantly different when followed by different letters $(P<0.05)$. 


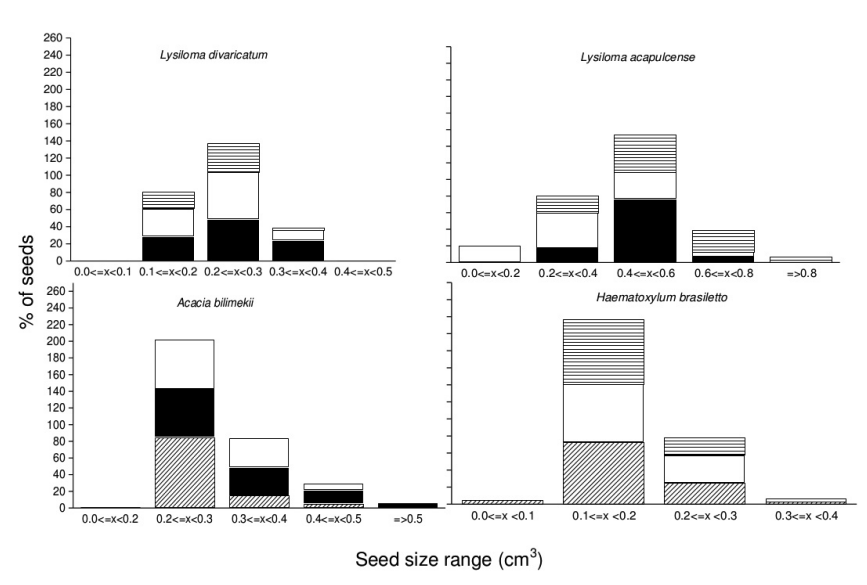

Figure 3. Seed size distributions among provenances of four species from the tropical dry forest of Morelos (Barranca Honda /////, Cañón de Lobos $\square$, El Tepehuaje $\square$, Quilamula $\equiv$ ).

acapulcense (seed size range $\sim 0.8 \mathrm{~cm}^{3}$ ) than in L. divaricatum (seed size range $<0.4 \mathrm{~cm}^{3}$ ); in the former species seeds from El Tepehuaje (with a distribution skewed towards the small seed size categories) and Quilamula (with a distribution skewed towards the larger categories), showed larger variation than those from Cañón de Lobos. Different provenances of $A$. bilimekii had a similar pattern of seed size variation, though only seeds from Cañón de Lobos were in the largest size category. Variability in seed size was low in all provenances of $H$. brasiletto, as most seeds were between 0.1 and $0.3 \mathrm{~cm}^{3}$ (Figure 3 ).

Effect of storage time and provenance on seed germination. Variation among species in seed viability (as shown

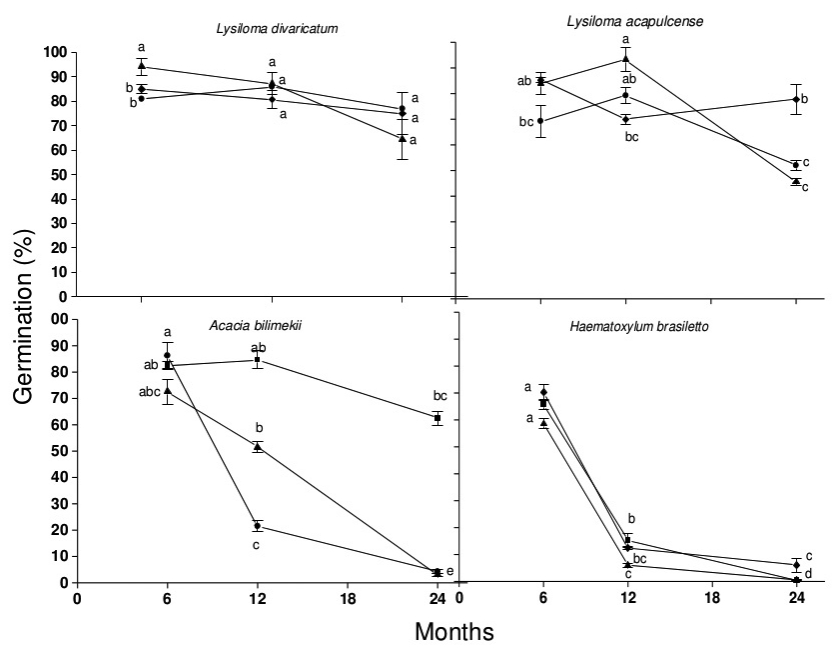

Figure 4. Mean germination ( \pm s.e.) after three storage periods (6, 12 and 24 months) of seeds from three different provenances of four species from the tropical dry forest of Morelos. $\square=$ El Tepehuaje; = Cañón de Lobos, $\boldsymbol{\Delta}=$ Quilamula, $\bigcirc=$ Barranca Honda. Means are significantly different when followed by different letters $(P<0.05)$. from germination trials) after different storage periods was large. The two Lysiloma species showed high germination capacity even 24 months after storage, while seeds of Acacia bilimekii and Haematoxylum brasiletto showed a large decline in germination after 12 months of storage at room temperature (Figure 4).

The effect of provenance on germination was significant in three out of four species, except for Lysiloma divaricatum (Table 2), and the significant interaction provenance $\times$ time indicates that germination changed with storage time at different rates among provenances. Mean germination capacity in Lysiloma divaricatum was around $80 \%$ in all provenances, and loss of viability through time was low and similar among the three of them (Figure 4), with final values of $65-77 \%$ at the end of the period.

The Lysiloma acapulcense seeds from Cañón de Lobos registered a slightly lower mean germination (67\%) than those from El Tepehuaje and Quilamula, which showed similar mean values (74 and $78 \%$, respectively). Seeds from El Tepehuaje and Cañón de Lobos showed a slight increase in germination percentage from 6 to 12 months, and thereafter a significant decline from month 12 to 24 , while germination of seeds from Quilamula did not change significantly through time, with a final mean germination percentage of $78 \%$, a significantly higher value than the one registered in the other two provenances (Figure 4). Therefore, differences among provenances increased through time. However, germination capacity was still relatively moderate ( $\geq 50 \%$ ) after 24 months of storage in all of them.

Seeds of Acacia bilimekii from Barranca Honda registered a significantly higher mean germination (77\%) than those from Cañón de Lobos and Tepehuaje (37 and 42\%, respectively), which were not different. The interaction provenance $\times$ storage time was also significant, as germination did not change through time in seeds from Barranca Honda, while there were large declines in those from El Tepehuaje and Cañón de Lobos, with a final mean value of 3-4\% vs. $63 \%$ in the former. Seeds from Cañón de Lobos showed significant decreases in germination between months 6-12 and 12-24, while in those from El Tepehuaje the only significant difference was between months 12 and 24 (Figure 4).

Table 2. Results of the analyses of variance of the effect of provenance and storage time in seed germination of four species from the tropical dry forest of Morelos.

\begin{tabular}{lccc}
\hline Species & $\begin{array}{c}\text { Provenance }(\mathrm{P}) \\
F\end{array}$ & $\begin{array}{c}\text { Time }(\mathrm{T}) \\
F\end{array}$ & $\begin{array}{c}\mathrm{P} \times \mathrm{T} \\
F\end{array}$ \\
\hline Lysiloma divaricatum & $0.58 \mathrm{~ns}$ & $6.53^{* *}$ & $2.48 \mathrm{~ns}$ \\
Lysiloma acapulcense & $5.02^{*}$ & $20.83^{* *}$ & $11.044^{* *}$ \\
Acacia bilimekii & $60.30^{* *}$ & $139.60^{* *}$ & $23.23 * *$ \\
Haematoxylum brasiletto & $17.41^{* *}$ & $641.37^{* *}$ & $3.77^{*}$ \\
\hline
\end{tabular}

$* P<0.05 ; * * P<0.01$ 
In Haematoxylum brasiletto mean germination values were rather low in all provenances, although significantly different: Quilamula (30\%), Barranca Honda (27\%), and El Tepehuaje (22\%). After six months of storage, germination was not different among provenances (with a mean value of $66 \%$ ), and decreased through time in a similar fashion in all of them, with a large decline between months 6-12 (Figure 4 ), after which mean germination was $\leq 15 \%$. Final germination of seeds from Quilamula was low (6\%), but slightly higher than in seeds from El Tepehuaje and Barranca Honda $(1 \%)$.

\section{Discussion}

Although some of the species included in this study are currently propagated in rural nurseries of the Mexican dry tropics, detailed information regarding their germination rates is scarce (but see Cervantes-Gutiérrez et al., 1996). There are still fewer studies addressing differences in seed size and germination patterns among provenances in TDF species, and thus our results may be considered an initial contribution to evaluate within species variability in these attributes. These results can also help to identify the best provenances for the study species at a regional level. Further research is necessary to establish the best provenances for different species and regions. The two Lysiloma species have a wide distribution in the Mexican tropical dry forests (Trejo-Vázquez, 1998), and three of the study species (with the exception of Acacia bilimekii) are also found in the TDF of Central America, so it is expected that further variation in seed size, germination, seed longevity, and seedling growth among provenances will be found, as more studies address these issues.

Differences among provenances in morphological and ecological characteristics, including seed size and germination, have been reported in several tropical species, such as Brosimun allicastrum (Lopez-Mata, 1987), Gliricida sepium (Ngulube, 1989), Prosopis cineraria (Arya et al., 1995), and Dalbergia sissoo (Vakshasya et al., 1992; Gera et al., 2000). In our case, seed size variation among provenances was significant in all the study species. Lysiloma acapulsence and Acacia bilimekii showed a larger variation in seed size than Haematoxylum brasiletto, which also had the smallest seeds. Seeds of the closely related species $H$. campechianum are similarly small (10-12 mm long vs. 9-12 $\mathrm{mm}$ in H. brasiletto; Niembro, 2002).

According to our results, seeds of the two Lysiloma species may be stored at room temperature for two years, as both species showed relatively high germination capacity ( $\geq$ $50 \%$ ) after being stored for 24 months, with larger figures for $L$. divaricatum. A previous study also reported that seed viability in stored seeds of $L$. divaricatum remained high for two years, while this period was slightly larger for $L$. acapulcense (Cervantes et al., 2001). In our case, differences in germination among provenances in $L$. divaricatum were not significant during the 24 months storage period, but in the case of $L$. acapulcense the larger seeds from Quilamula should be preferred if storage periods longer than a year are needed.

As in Lysiloma acapulcense, in Acacia bilimekii the provenance having the highest mean germination was also the one with the largest mean seed size. Differences in germinability among provenances at six months increased after 12 month of storage, with a large decline in those from Cañon de Lobos. Thus, Barranca Honda should be preferred when collecting seeds of this species in Morelos. Cervantes et al. (2001) found that seeds of A. bilimekii from Xalpatlahuac, Guerrero, kept a relatively high viability after three years of storage at room temperature, which may be due to large variability in seed longevity among provenances, but may also reflect differences in storage conditions (FAO, 1985). Although seeds of several species of Acacia keep their viability for long periods at room temperature (12-18 years, Doran et al., 1983), not all of them do, as seeds of A. harpophylla deteriorate rapidly unless stored at $2-4{ }^{\circ} \mathrm{C}$ (FAO, 1985).

Seeds of Haematoxylum brasiletto had a mean viability of $60-70 \%$ after six months of storage, a slightly lower value than those of the other study species. Although we did not perform germination tests of freshly collected seeds, an independent germination trial of seeds of this species (from El Tepehuaje) stored during approximately one month produced a slightly larger figure $(81 \%$; M. Cervantes unpublished data), so there seems to be a rapid decline in viability in this species, whose seeds may be in an intermediate position along the continuum between extreme orthodoxy and recalcitrance (Berjak and Pammenter, 2008). It would be worth investigating if the relatively rapid loss in viability found is related to reduced genetic variability, as trees of this species were harvested extensively during the XVI-XVII centuries, to extract textile dyes from its wood (haematoxylin, a sweet, colourless crystal that gives the wood its characteristic reddish color), and probably only small populations of low quality trees remained (Hobhouse, 1986). According to our results, seeds of this species cannot be stored at room temperature and should be germinated soon after being collected, within a six month period. As with seed size, differences in germinability through time among provenances, although significant, were rather low.

Information regarding changes in germination through time in seeds stored at room temperature will help to design seed collection and storage schedules in rural nurseries, which lack facilities such as cold rooms or refrigerators. Changes in viability in seeds stored at low temperatures are still needed and will be useful as storage facilities become available in some nurseries in the future. However, a previous study found that differences in germination of seeds stored at room temperature $\left(25 \pm 2{ }^{\circ} \mathrm{C}\right)$ and refrigerated 
$\left(-18{ }^{\circ} \mathrm{C}\right)$, in sealed flasks during two years were not significant in three of the study species (Cervantes et al., 2001).

The among-provenance variations in seed size and germination found in this study show the importance of including these variables in studies of plant propagation, especially for tropical dry forests species from Mexico, where information is still scarce and dispersed in local studies that are seldom published (Bonfil and Trejo, 2010). As stated by Ray and Brown (1994), more empirical data are needed to improve seed collection and processing techniques for dry forest trees.

\section{Acknowledgements}

Israel Ortiz Pedrosa and Ladislao Campusano helped to collect and clean the seeds; the former also helped with nursery work. Elena Sotelo-Boyás assisted seed measuring and recording germination, and Wolke Tobon helped with literature review. Tannis Beardmore and anonymous reviewers made useful suggestion that improved the manuscript. C. Bonfil thanks DGAPA-UNAM for economical support through project Papiit IN2186012. The information of the study sites is unpublished and does not correspond to any current program of the INIFAP.

\section{Literature cited}

Arya S., Bisht R.P., Tomar R., Toky O.P. and Harris P.J.C. 1995. Genetic variation in minerals, crude protein and structural carbohydrates of foliage in provenances of young plants of Prosopis cineraria (L.) Druce in India. Agroforestry Systems 29:1-7.

Baskin J.M. and Baskin C.C. 2001. Seeds. Ecology, Biogeography, and Evolution of Dormancy and Germination. Academic Press, San Diego.

Berjak P. and Pammenter N.W. 2008. From Avicennia to Zizania: seed recalcitrance in perspective. Annals of Botany 101:213228.

Bonfil C. 1998. The effects of seed size, cotyledon reserves and herbivory on seedling survival and growth in Quercus rugosa and $Q$. laurina (Fagaceae). American Journal of Botany 85:79-87.

Bonfil-Sanders C., Cajero-Lázaro I. and Evans R.Y. 2008. Seed germination of six Bursera species from central Mexico. Agrociencia 42:827-834.

Bonfil C. and Trejo I. 2010. Plant propagation and the ecological restoration of Mexican Tropical Deciduous Forests. Ecological Restoration 28:369-376.

Boyás D.J.C. 1991. Regionalización ecológica del estado de Morelos. En: Tapia U.F.M. Ed. Primeras Jornadas de Investigación en el Estado de Morelos, pp. 17-25, Universidad Autónoma del Estado de Morelos, Cuernavaca.

Boyás D.J.C., Cervantes S.M.A., Javelly G.J.M., Linares A.M.M., Solares A.F., Soto E.R.M., Naufal T.I. y Sandoval C.L. 1993. Diagnóstico Forestal del Estado de Morelos. Publicación Especial No. 7. Secretaría de Agricultura, Ganadería y Desarrollo Rural. Instituto Nacional de Investigaciones Forestales, Agrícolas y Pecuarias. Centro de Investigación Regional del Centro. Zacatepec.
Brook B.W., Sodhi N.S. and Bradshaw C.J.A. 2008. Synergies among extinction drivers under global change. Trends in Ecology and Evolution 23:453-460.

Bullock S.H. and Solís-Magallanes A. 1990. Phenology of canopy trees of a tropical deciduous forest in Mexico. Biotropica 22: 22-35.

Cervantes V., Arriaga V., Meave J. and Carabias J. 1998. Growth analysis of nine multipurpose woody legumes native from southern Mexico. Forest Ecology and Management 110:329341.

Cervantes G.V., López G.M., Salas N.N. y Hernández C.G. 2001. Técnicas para Propagar Especies Nativas de Selva Baja Caducifolia y Criterios para Establecer áreas de Reforestación. Facultad de Ciencias. Universidad Nacional Autónoma de México. México, D.F.

Cervantes S.M.A. and Sotelo B.M.E. 2002. Guías Técnicas para la Propagación Sexual de 10 especies Latifoliadas de Selva Baja Caducifolia en el Estado de Morelos. Publicación Especial No. 30. Secretaría de Agricultura, Ganadería, Desarrollo Rural, Pesca y Alimentación. Instituto Nacional de Investigaciones Forestales, Agrícolas y Pecuarias. Centro de Investigación Regional del Centro Zacatepec, México.

Cervantes-Gutiérrez V., Carabias-Lillo M.J. and Vázquez-Yanes C. 1996. Seed germination of woody legumes from deciduous tropical forest of southern Mexico. Forest Ecology and Management 82:171-184.

Doran J.C., Turnbull J.W., Boland D.J. and Gunn B.V. 1983. Handbook on seeds of dry-zone acacias. A guide for collecting, extracting, cleaning and storing the seed and for treatment to promote germination of dry-zone acacias. FAO, Rome.

Dorne A.J. 1981. Variation in seed germination inhibition of Chenopodium bonus-henricus in relation to altitude of plant growth. Canadian Journal of Botany 59:1893-1901.

García E. 2004. Modificaciones al sistema de clasificación climática de Köppen. Para adaptarlo a las condiciones de la República Mexicana. México, D. F. México: Instituto de Geografía, Universidad Nacional Autónoma de México, México, D.F.

FAO. Food and Agriculture Organization of the United Nations. 1985. Seed Storage. In: Willan R.L. Comp. A Guide to Forest Seed Handling with Special Reference to the Tropics. FAO Forestry Paper 20/2, Rome. <www.fao.org/docrep/006/AD232E/ AD232E00.HTM\#TOC> (consultado 16 de enero 2013).

Gera M., Gera N. and Ginwal H.S. 2000. Seed trait variation in Dalbergia sissoo Roxb. Seed Science and Technology 28:467-475.

Hobhouse H. 1986. Seeds of change: five plants that transformed mankind. Harper \& Row. New York.

Khurana E. and Singh J.S. 2000. Influence of seed size on seedling growth of Albizia procera under different soil water levels. Annals of Botany 86:1185-1196.

Lopez-Mata L. 1987. Genecological differentiation in provenances of Brosimum allicastrum - A tree of moist tropical forests. Forest Ecology and Management 21:197-208.

Metz J., Linacourt P., Kigel J., Harel D., Sternberg M. and Tielbörger K. 2010. Plant survival in relation to seed size along environmental gradients: a long-term study from semi-arid and Mediterranean annual plant communities. Journal of Ecology 98:697-704.

Miller P.M. 1999. Effects of deforestation on seed banks in a tropical deciduous forest of western Mexico. Journal of Tropical Ecology 15:179-188. 
Ngulube M.R. 1989. Genetic variation in seed germination and seedling growth of 24 Gliricidia sepium provenances. Forest Ecology and Management 28:1-6.

Niembro R.A. 2002. Haematoxylum campechianum L. In: Vozzo, J.A. Ed. Tropical Tree Seed Manual, pp. 497-499, USDA Forest Service, Agriculture Handbook 721, Washington, D.C.

Paz H. and Martínez-Ramos M. 2003. Seed mass and seedling performance within eight species of Psychotria (Rubiaceae). Ecology 84:439-450.

Primack R.B. 2010. Essentials of Conservation Biology. Sinauer Associates, Sunderland.

Ray G.J. and Brown B.J. 1994. Seed ecology of woody species in a Caribbean dry forest Restoration Ecology 2:156-163.

Rosenzweig M. L. 1995. Species Diversity in Space and Time. Cambridge University Press, Cambridge.

Sánchez-Azofeifa G.A. and Portillo-Quintero C. 2011. Extent and drivers of change of Neotropical seasonally dry tropical forests. In: Dirzo R., Young H.S., Mooney H.A. and Ceballos G. Eds. Seasonally Dry Tropical Forest. Ecology and Conservation, pp. 45-57, Island Press, Washington, D.C.

Singh J.S. and Singh V.K. 1992. Phenology of seasonally dry tropical forest. Current Science 63:684-689.

Thompson C.M. 1997. Zonificación de semillas en México. In: Vargas H.J.J., Bermejo V.B. y Ledig F.T. Eds. Manejo de Re- cursos Genéticos Forestales, pp. 67-88. Seminario-Taller sobre Manejo de Recursos Genéticos Forestales, Colegio de Postgraduados, Chapingo.

Trejo-Vázquez R.I. 1998. Distribución y diversidad de las selvas bajas de México: relaciones con el clima y suelo. Ph.D. thesis. Facultad de Ciencias. Universidad Nacional Autónoma de México. México, D.F. 210 pp.

Trejo I. and Dirzo R. 2000. Deforestation of seasonally dry tropical forest. A national and local analysis in Mexico. Biological Conservation 94:133-142.

Vakshasya R.K., Rajora O.P. and Mahendra S.R. 1992. Seed and seedling traits of Dalbergia sissoo Roxb.: seed source variation studies among ten sources in India. Forest Ecology and Management 48:265-275.

van Molkën T., Jorritsma-Wienk L.D., van Hoeck P.H.W. and de Kroon H. 2005. Only seed size matters for germination in different populations of the dimorphic Tragopogon pratensis subsp. pratensis (Asteraceae). American Journal of Botany 92:432437.

Wulff R.F. 1995. Environmental maternal effects on seed quality and germination. En: Kigel J. and Galili G. Eds. Seed Development and Germination, pp. 491-505, Marcel Dekker, New York.

Received: April 20th, 2013

Accepted: August 23rd, 2013 